
Email: Ippm.akip2@gmail.com

\title{
HUBUNGAN INDEKS MASSA TUBUH (IMT) TERHADAP KADAR TRIGLISERIDA PADA WANITA USIA 40-60 TAHUN
}

\author{
Hartini $\mathbf{H}^{1^{*}}$, Wiranti Febiola ${ }^{2}$ \\ ${ }^{1}$ Akademi Kesehatan John Paul II Pekanbaru \\ ${ }^{2}$ Mahasiswi Akademi Kesehatan John Paul II Pekanbaru \\ *Surat elektronik: hartini.tini214.@gmail.com
}

\begin{abstract}
ABSTRAK
Makanan diperlukan dalam pembentukan energi dalam tubuh. Makanan umumnya mengandung asupan gizi salah satunya adalah lemak. Lemak yang masuk ke dalam tubuh termasuk asam lemak dan trigliserida. Trigliserida adalah lemak darah yang berfungsi sebagai cadangan energi tubuh, isolator dan pelindung tubuh. Penentuan status gizi dilakukan dengan perhitungan indeks massa tubuh sebagai indikator dalam menilai obesitas. Penentuan Indeks Massa Tubuh (IMT) didapatkan dengan membandingkan Berat Badan (BB) terhadap Tinggi Badan (TB). Pengukuran IMT relatif lebih mudah, murah, cepat, dan sederhana. Penelitian ini bertujuan untuk menentukan hubungan indeks massa tubuh (IMT) terhadap kadar trigliserida pada wanita usia 40-60 tahun. Penelitian dilakukan secara observasi dan eksperimental. Sampel diambil mengunakan teknik purposive sampling. Hasil penelitian menunjukan dari 30 orang terdapat Indeks Massa Tubuh (IMT) kurus $(<17,5-18,5)$ sebanyak 3 orang $(10 \%)$, normal $(>18,5-25,0)$ sebanyak 14 orang $(46,7 \%)$, dan gemuk $(>25,0-27,0)$ sebanyak 13 orang $(43,3 \%)$. Berdasarkan kelompok rerata kadar trigliserida didapatkan trigliserida normal $(<150 \mathrm{mg} / \mathrm{dL})$ sebanyak 27 orang (90\%), trigliserida tinggi $(200-499 \mathrm{mg} / \mathrm{dL})$ sebanyak 3 orang $(10 \%)$. Data dianalisis menggunakan Uji Chi-Squarare dan didapatkan hasil $\mathrm{P}_{\text {Value }}(0,149)$ dan nilai $\alpha$ $(0,05)$, yang menunjukan bahwa tidak ada hubungan antara Indeks Massa Tubuh (IMT).
\end{abstract}

Kata Kunci: Indeks Massa Tubuh (IMT), Trigliserida

\section{ABSTRACT}

Food is needed in the formation of energy in the body. Foods generally contain nutrients intake, one of which is fat. Fats which are absorbed the body include fatty acids and triglycerides. Triglyceride are a type of fat found in blood which serves as a reserve supply of energy, insulator, and body protection. Assessment of nutritional status is done by calculating body mass index as an indicator in assessing obesity. Body Mass Index (BMI) is calculated by comparing Body Weight to Body Height. BMI measurement is relatively easier, cheaper, faster, and simpler. This research aimed to determine the correlation between body mass index (BMI) and triglyceride level in women aged 40-60 years. The methods of the research were observation and experiments. Samples were chosen with purposive sampling technique. The results showed that from 30 samples, there were 3 samples (10\%) classified as underweight $(<17.5-18.5), 14$ samples $(46.7$ $\%)$ classified as normal (>18.0-25.0), and 13 samples $(43,3 \%)$ categorized as overweight (>25.0-27.0), 27 out of 30 sampels (90\%) have normal triglyceride level $(<150 \mathrm{mg} / \mathrm{dL})$ where as three of 30 samples (10\%) have high triglyceride level (200-499 $\mathrm{mg} / \mathrm{dL})$. The data were analyzed with Chi-Square Test and obtained the result of $P_{\text {Value }}(0,149)$ and $\alpha(0,05)$, which showed that there was no correlation between BMI and triglyceride level.

Keywords: Body Mass Index (BMI), Triglyceride 


\section{PENDAHULUAN}

Makanan diperlukan dalam pembentukan energi dalam tubuh. Energi adalah salah satu hasil metabolisme karbohidrat, lemak, protein. Energi berfungsi sebagai zat tenaga untuk metabolisme, pertumbuhan, pengaturan suhu dan kegiatan fisik (McGuire dan Beerman, 2011 ; IOM, 2002 dalam Hardiansyah, 2016). Namun banyak orang kurang dalam memperhatikan pola makan yang sehat dan meluangkan waktunya untuk berolah raga karena banyak pekerjaan yang harus dikerjakan serta melupakan asupan makanan yang baik. Selain itu, gaya hidup modern zaman sekarang juga sudah banyak makanan junkfood atau makanan cepat saji. Hal ini sangat membahayakan khususnya untuk kasus yang berhubungan dengan kelebihan kalori dari asupan makanan (McGuire dan Beerman, 2011 ; IOM, 2002 dalam Hardiansyah, 2016).

Makanan umumnya mengandung asupan gizi, salah satunya adalah lemak. Lemak yang masuk kedalam tubuh termasuk asam lemak dan trigliserida. Trigliserida memiliki fungsi yaitu menyediakan cadangan energi tubuh, isolator, pelindung organ dan menyediakan asam-asam lemak esensial (Mahandan Escott 2008 dalam Hardiansyah, 2016). Jumlah lemak dan trigliserida yang ada di dalam darah melebihi batas normal akan menyebabkan penyakit beresiko seperti stroke iskemik, diabetes, dan dislipidemia (Hardhani, 2005 dalam Subarniyanti, 2015). Dislipidemia bisa terjadi karena ada kelainan metabolisme lipid dalam plasma darah yang menyebabkan tingginya kadar kolesterol total, trigliserida, Low Density Lipoprotein (LDL) dan penurunan kadar High Density Lipoprotein (HDL).

Berdasarkan Sitepu (2014) yang mengutip hasil penelitian Gibso (2005) menyatakan bahwa penentuan status gizi dilakukan dengan perhitungan indeks massa tubuh sebagai indikator dalam menilai obesitas. Hal ini karena indeks massa tubuh (IMT) berkorelasi dengan trigliserida dalam tubuh manusia. Trigliserida merupakan lemak dalam darah, jika lemak darah tinggi maka kadar trigliserida juga akan meningkat.

\section{TINJAUAN TEORI}

\section{Indeks Massa Tubuh (IMT)}

Indeks massa tubuh (IMT) dapat menjadi indikator atau menggambarkan kadar adipositas dalam tubuh seseorang dengan melihat berat badan dan tinggi setiap individu bersangkutan. Indeks massa tubuh (IMT) adalah nilai yang diambil dari perhitungan antara berat badan (BB) dan tinggi badan (TB). Penggunaan indeks massa tubuh (IMT) sebagai bahan baku pengukuran obesitas dapat digunakan untuk orang dewasa (Sugondo, 2009 dalam Nugraha, 2014). Rumus Indeks Massa Tubuh (IMT) adalah sebagai berikut :

$$
\mathrm{IMT}=\frac{\text { Berat Badan }(\mathrm{kg})}{\text { Tinggi Badan }(\mathrm{m}) \times \text { Tinggi Badan }(\mathrm{m})}
$$

Tabel 1. Klasifikasi Indeks Massa Tubuh (IMT)

\begin{tabular}{ccc}
\hline IMT & Kategori \\
\hline$<17,0$ & $\begin{array}{c}\text { Kekurangan berat } \\
\text { badan tingkat berat } \\
\text { Kekurangan berat } \\
\text { badan tingkat ringan }\end{array}$ & Kurus \\
& \\
$>18,0-18,5-25,0$ & Normal & Normal \\
$>25,0-27,0$ & $\begin{array}{c}\text { Kelebihan berat badan } \\
\text { tingkat ringan } \\
\text { Kelebihan berat badan } \\
\text { tingkat berat }\end{array}$ & \\
& Gemuk \\
&
\end{tabular}

Sumber : Depkes RI 1994

\section{Trigliserida}

Trigliserida merupakan lemak darah yang dibentuk oleh esterifikasi gliserol dan tiga asam lemak yang dibawa oleh lipoprotein serum. Proses pencernaan trigliserida dari asam lemak dalam diet (eksogenus) dan diantarkan ke aliran darah sebagai kilomikron (droplet lemak kecil yang diselubungi protein), yang memberikan tampilan seperti susu atau krim pada serum setelah mengonsumsi makanan yang tinggi kandungan lemaknya (Kee, 2008).

\section{Fungsi trigliserida}

Berdasarkan Anggeriani (2016) yang mengutip hasil penelitian Kartasapoetra, dkk. (2008) 
menyatakan bahwa fungsi utama lemak yaitu sebagai penghasil asam lemak esensial, sebagai pembangun tubuh, sebagai penghasil energi, sebagai pelarut vitamin tertentu seperti A, D, E, dan K.

\section{Metabolisme trigliserida}

Makanan yang masuk ke dalam tubuh akan dipecah salah satunya adalah trigliserida. Trigliserida dibentuk di hati yang merupakan dari hasil pembentukan lemak (Lehninger, 2013). Ada dua jalur pemecahan trigliserida yaitu jalur eksogen dan endogen.

Jalur eksogen adalah makanan yang masuk dalam tubuh diolah oleh usus dipecah dalam bentuk partikel lipoprotein atau kilomikron. Lipoprotein masuk ke aliran darah dan trigliserida diurai dengan bantuan enzim lipoprotein lipase sehingga terbentuk asam lemak bebas. Asam lemak bebas akan menembus jaringan bawah kulit dan sel otot untuk diubah menjadi trigliserida sebagai cadangan energi.

Jalur endogen merupakan jalur yang dalam hal ini trigliserida diserap oleh usus setelah mengalami hidrolisis dan masuk ke dalam plasma menjadi VLDL (Very Low Density Lipoprotein) dibentuk oleh hati dengan bantuan insulin tidak semua VLDL digunakan melainkan dipecah lagi menjadi LDL dan HDL.

\section{Faktor yang mempengaruhi kadar trigliserida}

Faktor yang dapat berpengaruh pada pembentukan lipid dibagi menjadi dua yakni faktor pendukung seperti pola makan, konsumsi alkohol, rokok, dan kurang olahraga, sedangkan faktor utama adalah genetik, usia, jenis kelamin (Anggeriani, 2016). Tubuh memerlukan asupan makanan salah satunya adalah lipid atau lemak. Lipid adalah senyawa organik berminyak atau berlemak yang tidak larut dalam air, yang dapat diekstrak dari sel dan jaringan oleh pelarut nonpolar. Jenis lipid yang paling banyak adalah trigliserida yang mempengaruhi kadar lemak darah (Lehninger, 2013).

Berdasarkan penelitian Rahmadani (2014) menyatakan bahwa wanita lebih tinggi peningkatan lemak dalam darah yaitu kadar trigliserida. Kadar trigliserida yang tinggi dapat membahayakan kesehatan karena beberapa lipoprotein yang tinggi kandungan trigliseridanya juga mengandung kolesterol.
Tabel 2. Batas nilai normal trigliserida

\begin{tabular}{ll}
\hline \multicolumn{1}{c}{ Kadar Trigliserida } & \multicolumn{1}{c}{ Klasifikasi } \\
\hline$<150 \mathrm{mg} / \mathrm{dL}(<1,70 \mathrm{mmol} / \mathrm{L})$ & Normal \\
$150-199 \mathrm{mg} / \mathrm{dL}(1,70-2,25 \mathrm{mmol} / \mathrm{L})$ & Batas Tinggi \\
$200-499 \mathrm{mg} / \mathrm{dL}(2,26-5,63 \mathrm{mmol} / \mathrm{L})$ & Tinggi \\
$>500 \mathrm{mg} / \mathrm{dL}(>5.65 \mathrm{mmol} / \mathrm{L})$ & Sangat Tinggi \\
\hline
\end{tabular}

\section{METODE PENELITIAN}

\section{Instrumen pelaksanaan}

Tabung vakum tanpa antikoagulan ukuran 3 cc, spuit, jarum (Nall), holder, Tourniqiut, spektrofotometer, kuvet, tabung reaksi, timbangan berat badan, meteran tubuh, kapas alkohol steril 70\%, kapas kering steril, pipet mikro, sentifuga, rak tabung.

Bahan yang digunakan adalah serum tanpa antikoagulan dan kit Reagen Trigliserida Glory Diagnostics.

\section{Pemisahan Serum}

Darah pasien yang terdapat di dalam tabung didiamkan selama 15-30 menit hingga membeku, setelah beku disentrifuge dengan kecepatan $3000 \mathrm{rpm}$ selama 10 menit untuk memisahkan dari sisa bekuan darah, serum segera diambil dan dimasukan ke tabung yang lain dengan mengunakan pipet mikro (Supriyati, 2015).

\section{Pemeriksaan Trigliserida}

Reagen dan sampel disiapkan pada suhu ruang. Masing-masing reagen dan sampel dimasukkan ke dalam tabung dan beri label:

Tabel 3. Komposisi reagen dan sampel

\begin{tabular}{cccc}
\hline Komposisi & Blanko & Sampel & Standar \\
\hline Reagen & $1,0 \mathrm{~mL}$ & $1,0 \mathrm{~mL}$ & $1,0 \mathrm{~mL}$ \\
Sampel & - & $10 \mu \mathrm{L}$ & - \\
Standard & - & - & $10 \mu \mathrm{L}$ \\
\hline
\end{tabular}

Blanko, sampel dan standar Dihomogenkan dan diinkubasi selama 5 menit pada suhu $37^{\circ} \mathrm{C}$. Selanjutnya blanko, sampel dan standar dibaca absorbannya dengan spektofotometer pada panjang gelombang $500 \mathrm{~nm}$.

\section{HASIL DAN PEMBAHASAN}

\section{Hasil}

Penelitian hubungan Indeks Massa Tubuh (IMT) terhadap kadar trigliserida 
dilakukan pada wanita usia 40-60 tahun dengan sampel sebanyak 30 orang yang memiliki berat badan bervariasi, hasil didapatkan sebagai berikut:

Tabel 4. Kelompok berdasarkan Indeks Massa Tubuh (IMT) sampel

\begin{tabular}{ccc}
\hline$(\mathrm{IMT}) *\left(\mathrm{~kg} / \mathrm{m}^{2}\right)$ & $\mathrm{f}$ & $(\%)$ \\
\hline Kurus $(<17,5-18,5)$ & 3 & 10 \\
Normal $(>18,5-25,0)$ & 14 & 46,7 \\
Gemuk $(>25,0-27,0)$ & 13 & 43,3 \\
\hline Total & 30 & 100 \\
\hline
\end{tabular}

*Sumber: Depkes RI 1994

Berdasarkan tabel 3 diperoleh bahwa IMT sampel pada kelompok normal $(>18,5-$ $\left.25,0 \mathrm{~kg} / \mathrm{m}^{2}\right)$ mempunyai jumlah tinggi sebanyak 14 orang $(46,7 \%)$, kelompok IMT gemuk $\left(>25,0-27,0 \mathrm{~kg} / \mathrm{m}^{2}\right)$ sebanyak 13 orang (43,3\%), dan yang paling sedikit berada pada IMT kurus $\left(<17,5-18,5 \mathrm{~kg} / \mathrm{m}^{2}\right)$ sebanyak 3 orang $(10 \%)$. Hal tersebut kemungkinan karena asupan energi responden sesuai dengan jumlah yang dibutuhkan oleh tubuh sehingga tidak terjadi penimbunan energi dalam bentuk lemak sebagai cadangan energi yang akan berpengaruh pada berat badan responden (Hidayati, 2017).

Tabel 5. Berdasarkan kadar trigliserida sampel

\begin{tabular}{llll}
\hline $\begin{array}{l}\text { Kadar trigliserida } \\
(\mathrm{mg} / \mathrm{dL})^{*}\end{array}$ & Rerata & $\mathrm{f}$ & $(\%)$ \\
\hline Normal $(<150)$ & 99 & 27 & 90 \\
Batas Tinggi $(151-199)$ & 0 & 0 & 0 \\
Tinggi (200-499) & 260 & 3 & 10 \\
Sangat Tinggi $(>500)$ & 0 & 0 & 0 \\
\hline Jumlah & - & 30 & 100 \\
\hline
\end{tabular}

Penentuan hasil pengukuran kadar trigliseirda menunjukan bahwa 90\% sampel memiliki kadar trigliserida normal dan $10 \%$ kadar trigliserida tinggi. Kadar trigliserida yang tinggi biasanya disebabkan oleh kelebihan karbohidrat, lipid sehingga terjadi penumpukan pada pembuluh darah yang menyebabkan metabolisme akan terganggu.

Pada penelitian didapatkan kelompok Indeks Massa Tubuh (IMT) gemuk memiliki rerata kadar trigliserida sebesar $132 \mathrm{mg} / \mathrm{dL}$, kelompok Indeks Massa Tubuh (IMT) kurus dengan rerata kadar trigliserida sebesar 127 mg/dL dan kelompok Indeks Massa Tubuh (IMT) normal rerata kadar trigliserida sebesar $99 \mathrm{mg} / \mathrm{dL}$. Selanjutnya penelitian dilanjutkan dengan uji analisis statistika yaitu Uji ChiSquare.

Uji Chi-Square termasuk salah satu alat uji dalam statistik yang dipakai untuk menguji kesesuaian data sampel sebagai penunjang hipotesis yang menyatakan bahwa populasi asal sampel tersebut mengikuti suatu distribusi yang telah ditetapkan (Santoso, 1996). Berdasarkan uji Chi-Square menunjukkan hasil uji $\mathrm{P}_{\text {value }}$ lebih besar dari $\alpha$ $(0,149>0,05)$ maka, hal tersebut berarti bahwa tidak ada hubungan antara Indeks Massa Tubuh (IMT) terhadap kadar trigliserida. Hal ini disebabkan beberapa faktor yaitu asupan lemak, pola makan, dan faktor usia. Sesuai dengan pernyataan Hidayati, dkk, (2015) yang menyatakan bahwa kadar trigliserida dalam darah dapat dipengaruhi oleh peningkatan asupan lemak, sehingga kadar trigliserida akan meningkat (hipertrigliseridemia) (Syarief, Fatimah, 2011 dalam Putri dan Isti, 2015).

\section{Pembahasan}

Hasil penelitian menunjukkan responden memiliki Indeks Massa Tubuh (IMT) kelompok normal 46,7\%. Hal tersebut kemungkinan karena asupan energi responden sesuai dengan jumlah yang dibutuhkan oleh tubuh sehingga tidak terjadi penimbunan energi dalam bentuk lemak sebagai cadangan energi yang akan berpengaruh pada berat badan responden (Hidayati, 2017).

Penentuan hasil pengukuran kadar trigliserida menunjukan bahwa $90 \%$ sampel memiliki kadar trigliserida normal dan 10\% kadar trigliserida tinggi. Kadar trigliserida yang tinggi biasanya disebabkan oleh kelebihan karbohidrat, lipid sehingga terjadi penumpukan pada pembuluh darah yang menyebabkan metabolisme akan terganggu.

Pada penelitian didapatkan kelompok Indeks Massa Tubuh (IMT) gemuk memiliki rerata kadar trigliserida sebesar $132 \mathrm{mg} / \mathrm{dL}$, kelompok Indeks Massa Tubuh (IMT) kurus dengan rerata kadar trigliserida sebesar 127 mg/dL dan kelompok Indeks Massa Tubuh (IMT) normal rerata kadar trigliserida sebesar $99 \mathrm{mg} / \mathrm{dL}$. Selanjutnya penelitian dilanjutkan dengan uji analisis statistika yaitu Uji ChiSquare.

Uji Chi-Square termasuk salah satu alat uji dalam statistik yang dipakai untuk menguji kesesuaian data sampel sebagai 
penunjang hipotesis yang menyatakan bahwa populasi asal sampel tersebut mengikuti suatu distribusi yang telah ditetapkan (Santoso, 1996). Berdasarkan uji Chi-Square menunjukkan hasil uji $\mathrm{P}_{\text {value }}$ lebih besar dari $\alpha$ $(0,149>0,05)$ maka, hal tersebut berarti bahwa tidak ada hubungan antara Indeks Massa Tubuh (IMT) terhadap kadar trigliserida. Hal ini disebabkan beberapa faktor yaitu asupan lemak, pola makan, dan faktor usia. Sesuai dengan pernyataan Hidayati, dkk, (2015) yang menyatakan bahwa kadar trigliserida dalam darah dapat dipengaruhi oleh peningkatan asupan lemak, sehingga kadar trigliserida akan meningkat (hipertrigliseridemia) (Syarief, Fatimah, 2011 dalam Putri dan Isti, 2015).

Pola makan dapat mempengaruhi kadar trigliserida, dapat dilihat pada hasil kuesioner bahwa responden secara rutin mengkonsumsi sayuran sebanyak 19 sampel $(63,4 \%)$ dan sebanyak 23 sampel $(76,6 \%)$ tidak mengkonsumsi junkfood (makanan cepat saji). Hal ini mendukung hasil penelitian didapatkan sampel yang memiliki kadar trigliserida normal $(150 \mathrm{mg} / \mathrm{dL})$ sebesar $90 \%$. Konsumsi junkfood (makanan cepat saji) merupakan sumber lemak yang tinggi sehingga dapat meningkatkan trigliserida (Hidayati, 2017).

\section{KESIMPULAN DAN SARAN}

\section{Kesimpulan}

1. Berdasarkan Indeks Massa Tubuh (IMT) sampel dikelompokan atas: kurus $(<17,5-$ $18,5)$ sebanyak 3 orang $(10 \%)$, normal $(>18,5-25,0)$ sebanyak 14 orang $(46,7 \%)$, dan gemuk $(>25,0-27,0)$ sebanyak 13 orang $(43,3 \%)$.

2. Berdasarkan Kadar Trigliserida pada sampel dikelompokan atas: kadar normal $(<150 \mathrm{mg} / \mathrm{dL})$ sebanyak 27 orang $(90 \%)$, kadar tinggi (200-499 mg/dL) sebanyak 3 orang $(10 \%)$.

3. Berdasarkan hasil Uji Chi-Square ditemukan bahwa tidak terdapat hubungan bermakna antara Indeks Massa Tubuh (IMT) dengan kadar trigliserida darah pada wanita usia 40-60 tahun.

\section{Saran}

Perlu dilakukan penelitian lanjutan dengan pengambilan sampel pada usia yang berbeda.

\section{DAFTAR PUSTAKA}

Antoni, S. 2010. Analisa Kandungan Formalin Pada Ikan Asin. Skripsi, Universitas Islam Negeri Sultan Syarif Kasim Riau, Pekanbaru.

Anggeriani, R. 2016. Hubungan Indeks Massa Tubuh (IMT) Dengan Kadar Trigliserida Darah Pada Pegawai Universitas Abdurab Tahun 2016. Karya Tulis Ilmiah, Akademi Analis Kesehatan, Yayasan Fajar, Pekanbaru.

Arifnaldi, S.M. 2014. Hubungan Kadar Trigliserida dengan Kejadian Stroke Iskemik di RSUD Sukoharjo, Skripsi, Fakultas Kedokteran, Universitas Muhamaddiah, Surakarta.

Hardiansyah., Riyadi, H., Napitupulu, Victor. 2016. Kecukupan Energi, Lemak dan Karbohidrat. Erlangga, Jakarta.

Hidayati, R.D. 2017. Hubungan Asupan Lemak Dengan Kadar Trigliserida Dan Indeks Massa Tubuh Sivitas Akademika UNY. Jurnal Prodi Biologi Vol 6.

Kee, L. J. 2008. Laboratory And Diagnostic Tests With Nursing Implications. Dalam Kurnianingsih, S., Widyastuti, P., Chayaningrum, R., Rahayu, S (Eds. 6), Pedoman pemeriksaan Laboratorium \& Diagnostik: Pearson Education.

Lehninger, L.A. 2013. Dasar-Dasar Biokimia, diterjemahkan oleh Thenawijaya, $M$. Erlangga, Jakarta.

Nugraha, A. 2014. Hubungan Indeks Massa Tubuh Dengan Kadar Kolesterol Total Pada Guru Dan Karyawan SMA Muhammadiyah 1 Dan 2 Surakarta. Skripsi, Fakultas Kedokteran, Universitas Muhammadiyah, Surakarta.

Putri. R. S., Isti, D, 2015. Obesitas Faktor Resiko Peningkatan Kadar Trigliserida. Jurnal Majority Volume 4 Nomor 9.

Ramadhani, A. 2014. Perbedaan Kadar Trigliserida Sebelum Dan Setelah Pemberian Sari Bengkuang (Pachyrrhizus erosus) Pada Wanita, Skripsi, Fakultas Kedokteran, Universitas Diponegoro, Semarang.

Santoso, Singgih. 1996. Mengelolah Data Statistik Secara Profesional Versi 7.5. PT Elex Media Komputindo, Jakarta.

Sitepu, W.I. 2014. Hubungan Antara Indeks Massa Tubuh Dengan Kadar Profil 
Lipid pada Pasien Dewasa di Bagian Penyakit Dalam Rumah Sakit PHC Surabaya, Skripsi, Prodi Pendidikan Dokter, Universitas Katolik Widya Mandala, Surabaya.

Subarniyanti, T. 2016. Pemeriksaan Kadar Trigliserida Pada Mencit Setelah Diberikan Jus Wortel (Daucus carota. L). Karya Tulis Ilmiah, Akademi Analis Kesehatan Yayasan Fajar, Pekanbaru.

Supriyati. 2015. Perbedaan Hasil Pemeriksaan Bilirubin Total Dan Direk Pada Serum Ikterik Dengan Dan Tanpa Pengenceran. Karya Tulis Ilmiah, Akademi Analis Kesehatan, Universitas Muhammadiah Semarang.

Wongkar, D., Ticoalu, R. H., Wowor, J. F. 2013. Perbandingan Kadar Trigliserida Darah Pada Pria Perokok Dan Bukan Perokok. Jurnal e-Biomedik (eBM), Volume 1, Nomor 2. 